体力科学 (2009) $58,91 \sim 98$

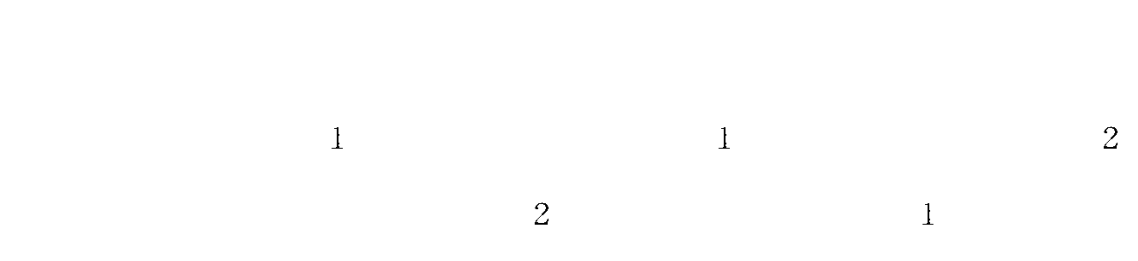

\title{
MUSCLE STRENGTH AND ELECTROMYOGRAPHY ANALYSIS OF THE NECK DURING CHIN-IN POSTURE
}

\author{
YaSuTOSHI ICHIKI, Yukio URABE, KaZUShige IDE, \\ TAKESHI AKIMOTO and AYA KAGIMORI
}

\begin{abstract}
Injuries of the cervical spine occur in contact sports. Generally, muscle strengthening training of the neck is performed to prevent injuries of the cervical spine. Isometric resistance training with chin-in posture exercise is recommended for strengthening the neck. However, muscle strength and electromyography(EMG) date for chin-in posture have not been reported. The purpose of this study was to validate muscle strength and EMG testing during chin-in posture. Subjects were fifteen healthy men without pathological conditions in the neck. Muscle strength date and EMG measurements were taken for maximal voluntary isometric contraction(MVIC)flexion and extension actions during normal and chin-in posture. Subjects performed MVIC using a handheld dynamometer and surface EMG was recorded sternocleidomastoid, scalenus, upper trapezius, and splenius muscles. Results of chin-in posture showed a significant increase in muscle strength and EMG of all muscles. These results indicate the beneficial effect of chin-in posture which can increase muscle strength and prevent injuries of the neck.
\end{abstract}

(Jpn. J. Phys. Fitness Sports Med. 2009, $58: 91 \sim 98$ )

key word : chin-in posture, muscle strength of the neck, electromyography analysis.

I . 緒言

アメリカンフットボールやラグビーなどのコンタ クトスポーツにおいて, 頊椎捻挫やバーナー症候群 などの頝部外傷発生率は，1 試合平均 1.35 例との報 告がある1).これは他のスポーツと比較して頚部外 傷の発生頻度が高く，重大な事故に発展することか ら特に注意を要する.さらに, 再発を繰り返す例も みられ 現場への早期復帰と再発の予防が望まれる . これらの頚部外傷の予防策として, 攧部筋力の向上 を図ることが一般的に行われている.

高澤ら ${ }^{2)}$ は頚部を過度に屈曲しないように前方を 見て，軽く顎を引き，胸を張り，肩甲帯をすぼめな い(挙上しない) ようにする姿勢が重要だと述べて
いる .この姿勢を保つことで頚部の筋収縮に集中し やすくなり，腹筋や背筋群の協調運動も行いやすく なるとしている．また，黑澤ら ${ }^{3)}$ はこのような姿勢 を保つことを意識させた頚部等尺性収縮のエクササ イズを推奨している．

川野 ${ }^{4)}$ も同樣に，頚部を屈曲させずに顎を水平に 後方に引いた状態での頝部筋力トレーニングを推奨 している こニは ,いわゆる「チンイン $\left(\right.$ chin-in $^{5}{ }^{5)}$ と呼ばれる姿勢である . 筋肉でいえば , 後頚部の頚 椎伸展筋群に加え, 难椎の前側方部の胸鎖乳突筋， 斜角筋群などが同時収縮を起こすことで頝部全体に 胸郭がロックされた状態である.さらに頝部外傷の 予防に際して，反射的にチンインできるようにする ことは重要であるとされている .

\footnotetext{
${ }^{1)}$ 広島大学大学院保健学研究科スポーツリハビリ Department of Sport Rehabilitation, Division of PT \& OT Sciences テーション学研究室 干734-8551 広島県広島市南区霞1-2-3

2) 広島大学医学部保健学科理学療法学専攻 干734-8551 広島県広島市南区霞1-2-3 Graduate School of Health Sciences, Hiroshima University Division of Physical Therapy, Institute of Health Sciences Faculty of Medicine, Hiroshima University
} 
しかし, チンイン姿勢時に発揮される頝部筋力と 頊部筋活動について述べたものは少ない，乥こで本 研究は, 健常男性の通常姿勢時とチンイン姿勢時の 頚部筋力および筋活動を測定し比較することで, チ ンイン姿勢時の頚部筋力と筋活動を明らかにするこ ととした . チンイン姿勢時にみられる筋活動が妥当 なものと考えられるなら，この姿勢によって筋活動 が高まり，今後の頚部筋力トレーニングおよび頚部 外傷予防の一助を得ることになると考え研究を実施 した。

\section{II . 対象および方法}

対象は頚部に特別な既往のない健康成人男性15名 とした. 年齢 (平均 $\pm S D$ ) $22.8 \pm 1.4$ 歳, 身長 173.5 $\pm 5.8 \mathrm{~cm}$, 体重 $63.3 \pm 6.4 \mathrm{~kg}$ であった. 本研究は広 島大学大学院保健学研究科心身機能生活制御科学講 座倫理委員会の承認を得て行った (承認番号0743).

通常姿勢とチンイン姿勢の違いを図 1 に示す.両 姿勢での最大等尺性栢部筋力および筋活動を記録し た (図 2 ). 頚部筋力はハンドヘルドダイナモメー タ (Micro FET II, Hoggan Health社) を用いて屈曲， 伸展を測定した . 測定肢位は津山ら ${ }^{6)}$ の方法に準じ て，対象を臥位とし両肩と大腿部を固定し，等尺性 筋力の測定時間は 3 秒間とした $\left.{ }^{7}\right)$.

难部筋活動の記録には表面筋電図 (Personal-EMG， 追坂電子機器社) を用いた。記録用電極は, 生体用
表面電極 (blue sensor, Ambu A/S) を使用し, 双 極誘導法を用いた，事前に皮膚表面を皮膚前処理剂 (skinpure, 日本光電工業株式会社) で研磨し, アル コール綿で清拭した . 導出筋は右側の胸鎖乳突筋 (sternocleidomastoid: SCM), 斜角筋 (scalenus: SC), 僧帽筋上部線維 (upper trapezius: UT), 板状筋 (splenius : SPL) の計 4 筋とし, アース電極は肩峰

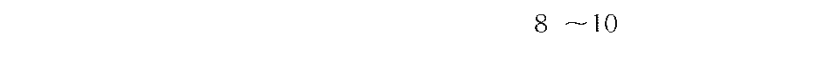
間距離は $20 \mathrm{~mm}$ とした (図 3 ). EMGのアナログ信 号をサンプリング周波数 $1000 \mathrm{~Hz}$ で A/D変換後 パーソナルコンピュータに取り込んだ . ハイパスフ イルターは $10 \mathrm{~Hz}$ 以下とした . 収録した生波形は， EMG 研究用ソフトウェア (BIMTUS-Video, キッセ イコムテック株式会社) を用いて root mean square (RMS) に変換した . 各筋の活動量は Manual Muscle Testing (MMT $)^{11)}$ に基づいた 3 秒間の最大等尺性 収縮時の間の 1 秒間の RMS を $100 \%$ として正規化し 比較に用いた。

統計処理には, エクセルアドインソフト (Statcel 2, オーエムエス出版) を用いた . 通常姿勢時とチ ンイン姿勢時での筋力および筋活動の統計学的検定 には対応のある $\mathrm{t}$ 検定を用いた . また , チンイン姿 勢時における各筋の活動量の増加率の検定には一元 配置分散分析を用いた．弚れ光れ危険率 $5 \%$ 末満を 有意とした。
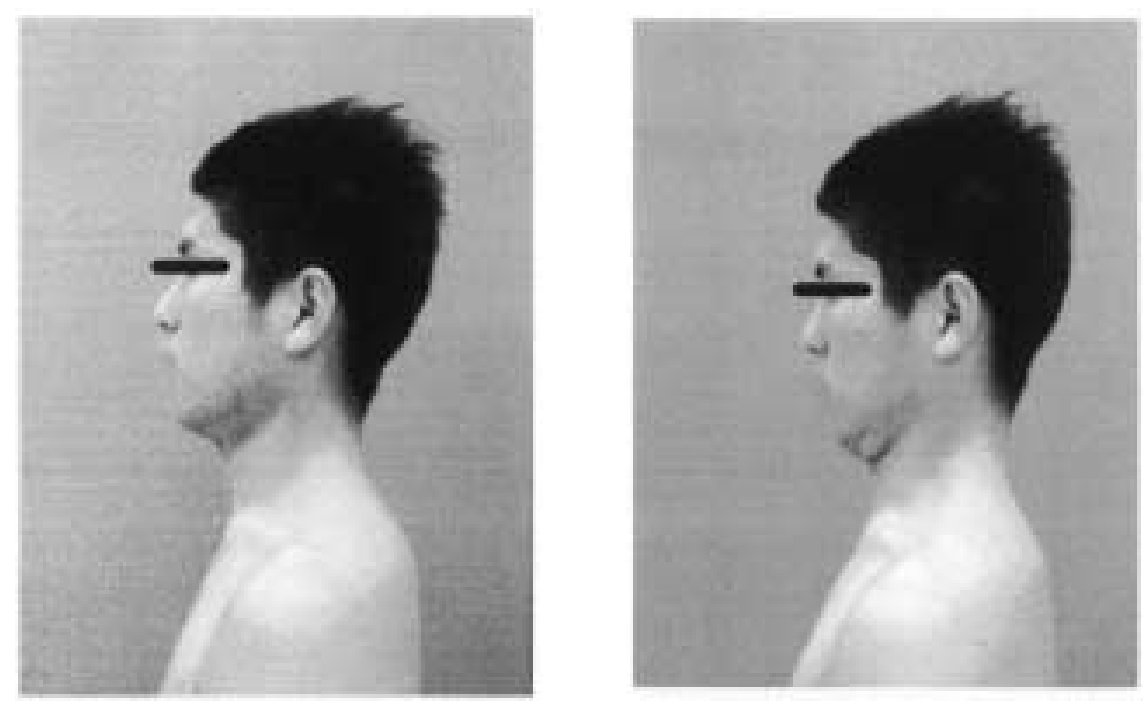

Fig. 1. Normal pusture (left) and chin-in posture (rigth). Chin-in posture is the state drawn the jaw behind horizontally, and fixed the neck to the chest. 


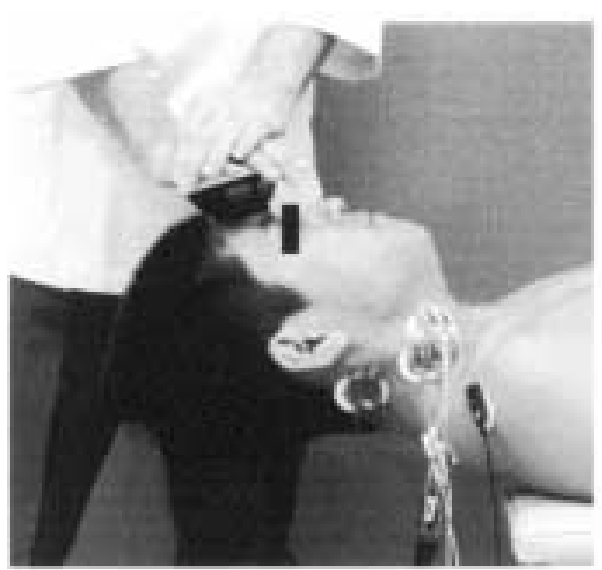

(a)

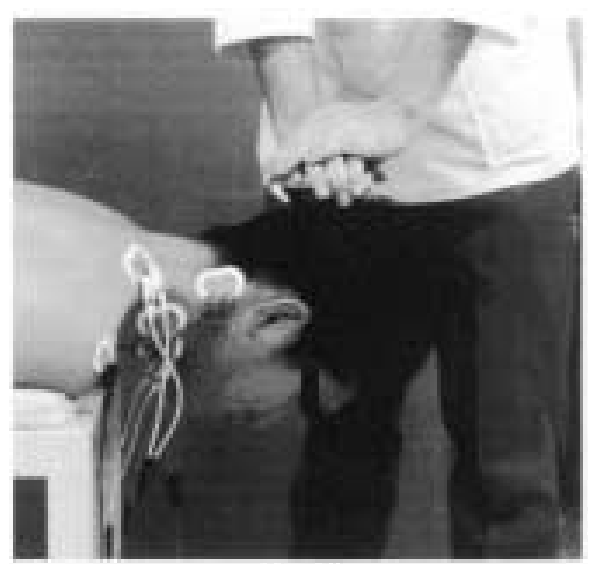

(b)

Fig. 2. Measurement of muscle strength and EMG.

(a ) Flexion strength and EMG

(b) Extension strength and EMG

III . 結

果

\section{1. 頚部筋力}

図 4 に頚部屈曲および伸展筋力を示す . 屈曲筋力 は通常姿勢で $129.8 \pm 41.5 \mathrm{~N}$, チンイン姿勢で 138.1 $\pm 41.0 \mathrm{~N}$ であった . 伸展筋力は通常姿勢で $238.7 \pm$

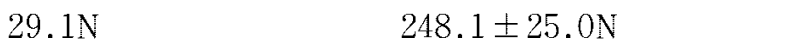
屈曲, 伸展筋力ともにチンイン姿勢時の方が有意に 高かった $(\mathrm{p}<0.05)$.

\section{2. 頚部筋活動}

図 5 に通常姿勢およびチンイン姿勢時の頝部筋の 活動量を示す . 屈曲時の筋活動は, 通常姿勢で胸鎖 乳突筋はMVCに対して $82.3 \pm 19.5 \%$, 斜角筋は
$87.1 \pm 29.7 \%$ ，僧帽筋上部線維は $37.8 \pm 37.2 \%$, 板 状筋は $76.4 \pm 19.6 \%$ であった .チンイン姿勢では， 胸鎖乳突筋は $93.9 \pm 26.0 \%$, 斜角筋は $100.5 \pm$ $34.9 \%$ ，僧帽筋上部線維は $51.3 \pm 48.1 \%$ ，板状筋は $94.6 \pm 34.7 \%$ であった . また，㑯部伸展時の筋活動 は，通常姿勢で胸鎖乳突筋は $7.8 \pm 6.7 \%$, 斜角筋は $29.2 \pm 11.3 \%$ ，僧帽筋上部線維は $20.5 \pm 16.4 \%$ ，板 状筋は $80.7 \pm 13.4 \%$ であった . チンイン姿勢では 胸鎖乳突筋は $21.7 \pm 21.7 \%$,斜角筋は $34.1 \pm 16.0 \%$ 僧帽筋上部線維は $28.8 \pm 22.2 \%$ ，板状筋は $87.5 \pm$ $15.1 \%$ であった．屈曲，伸展ともに，すべての筋の 活動量においてチンイン姿勢時の方が有意に高かっ た $(\mathrm{p}<0.05)$.

チンイン姿勢時における各筋の活動量の増加率に

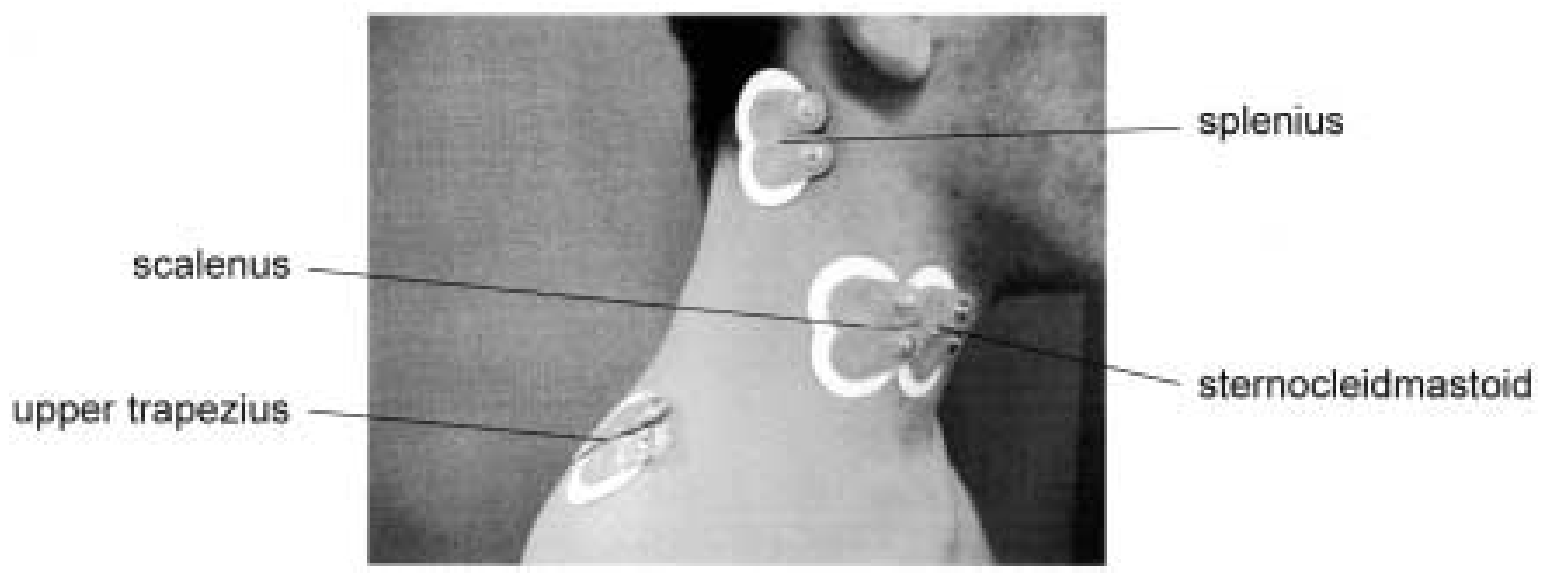

Fig. 3. Location of electrodes on a subject. 

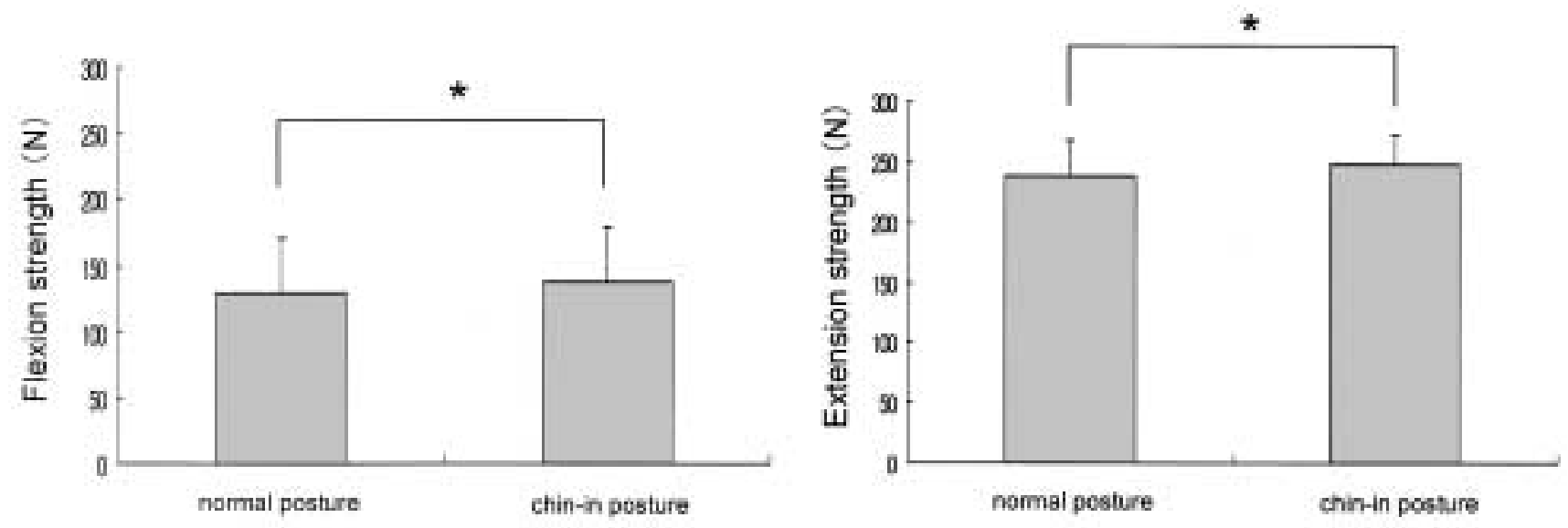

Fig. 4. Neck strength during normal posture and chin-in posture. ${ }_{p}<<0.05$

ついて, 結果を表 1 によとめた . 屈曲時は, 胸鎖乳 突筋で $13.6 \pm 15.7 \%$ ，斜角筋で $16.1 \pm 19.2 \%$ ，僧 帽筋上部線維で $62.2 \pm 84.1 \%$ ，板状筋で $24.6 \pm$ $35.4 \%$ であり，僧帽筋上部線維の活動量の増加率 が胸鎖乳突筋，斜角筋に対して有意に高かった $(\mathrm{p}$ $<0.05)$. 伸展時は胸鎖乳突筋で $182.8 \pm 176.3 \%$ ， 斜角筋で $16.3 \pm 29.3 \%$ ，僧帽筋上部線維で $47.6 \pm$ $38.7 \%$ ，板状筋で $9.2 \pm 12.4 \%$ であり，胸鎖乳突筋 の活動量の増加率が斜角筋, 僧帽筋上部線維, 板状 筋に対して有意に高かった $(p<0.01)$.

\section{N. 考察}

スポーツ活動中において, 䫝部が他の関節と大 きく異なる点は「関節を動かす」という動作に加え， 「炎の部位を固定し安定させる」という等尺性運動 (isometric) 的な使い方が圧倒的に多いことであ る ${ }^{3)}$. 頚部周囲筋は同時収縮することにより頚椎柱 を短縮させる軸圧として働き, 頚椎列を安定化させ ると考えられている ${ }^{12)}$. フットボールなどのコン タクトスポーツで起こる頚部の重症外傷のメカニズ ムとして, 頚椎の軽度屈曲位による垂直力, 過屈曲 力や過伸展力, 回旋力などが作用していることから 13)，14)，瞬時に頝部を固定するために筋を働かせる 必要がある. 㔬れゆえ, 頚部の筋力強化方法として は等尺性収縮を用いた運動や，さまざまの stability exercise が推奨されている2),4) .この際に, 頚部リ ハビリテーションにおける基本姿勢であるチンイン の状態を意識させることが重要であると考えられて (る2) -4).
本研究は, 通常姿勢時とチンイン姿勢時の頚部筋 力および筋活動を測定し比較することで, チンイン 姿勢の効果を検討した . 今回の結果より，チンイン 姿勢の方が発揮される筋力および筋活動がより高ま ることを確認できた .これはチンイン姿勢をとるこ とにより，胸鎖乳突筋，斜角筋などの屈曲筋群や僧 帽筋上部線維 板状筋などの伸展筋群が同時収縮し， 筋活動が高まった結果であると考える．これが頚部 筋力発揮の増加につながったと思われる．つまり， 通常姿勢とチンイン姿勢とでは異なる筋収縮の樣式 を示すといえよう．また，チンイン姿勢時における 各筋の活動量の増加率を検討した結果，屈曲時には 僧帽筋上部線維，伸展時には胸鎖乳突筋の活動量の 増加率が大きかった .この姿勢をとることで各運動 方向において, 通常姿勢では活動量の少ない筋の活 動量も増加したといえる．つまり，この2 筋の活動 量の増加か㳥部筋力発揮の増加に最も影響を与えた ものと考える .

頚部トレーニングにおけるチンイン姿勢の有効性 について考えたい .コンタクトスポーツにおける頚 部外傷の予防策として筋力強化が多くとなえられて (いる(1),6),22). 特にアメリカンフットボールやラグ ビーのタックル時には前方から外力を受けることが 多く，难部の過伸展を防ぐために屈曲の主動作筋で ある胸鎖乳突筋の強化が必要である . 屈曲筋力を強 化しなければ，頚部の傷害発生率が高くなるとの報 告もある ${ }^{15), 16)}$.さらに, Bauer ら ${ }^{17)}$ は頭部に強い 衝撃が加わる際, 僧帽筋よりも先に胸鎖乳突筋が活 動し, この先行的な筋活動の役割が重要であるとし 
ている . 本研究の結果より，チンイン姿勢時に胸鎖 乳突筋の筋活動が高まったことから，チンイン姿勢 で頚部トレーニングを行うことで効率よく胸鎖乳突 筋を鍛えることができると思われる．

僧帽筋上部線維は後頭骨, 項勒帯に起始し, 鎖骨 に停止する．この機能解剖学的観点から, 僧帽筋上 部線維は頚部伸展運動の動作筋であるとともに頭頚 部と体幹を固定する役割を果たしている．このこと から, 㑯部周囲筋のみならず僧帽筋上部線維の強化 も重要であるといわれている(8),19) . さらに, 岡本 $ら^{20)}$ は頚部の損傷事故は䫁椎中位から下位に多く 発生することから肩上部を強化することが重要であ ると述べている.しかし, Coneley ら ${ }^{21)}$ は, MRIの $\mathrm{T} 2$ 值を用いて頚部伸展時の頚部筋の働きを調べた 結果, 多裂筋, 頭頚半棘筋, 頭板状筋, 頭頚最長筋
が主動的に働き，僧帽筋の働きは少なかったと報告 している.本研究においても頚部伸展時の僧帽筋上 部線維の活動量は板状筋に比べて少なく，この報告 と一致している．このため，僧帽筋のトレーニング を行う際, 难部の等尺性運動だけでは不十分である と思われる . しかし, チンイン姿勢で等尺性運動を 行うことで, 僧帽筋上部線維の活動量を大幅に増加 させることができるという点で有効になる可能性が ある．これらのことから，チンイン姿勢での頝部卜 レーニングは, 胸鎖乳突筋や僧帽筋上部線維などの 重要とされる筋を効率よく鍛えることができるかも しれない.

一般的に頚部のトレーニングは等張性および等尺 性収縮による運動にて行われていることが多い．し かし, 重い錘を頭からぶら下げて頝椎を屈曲・伸

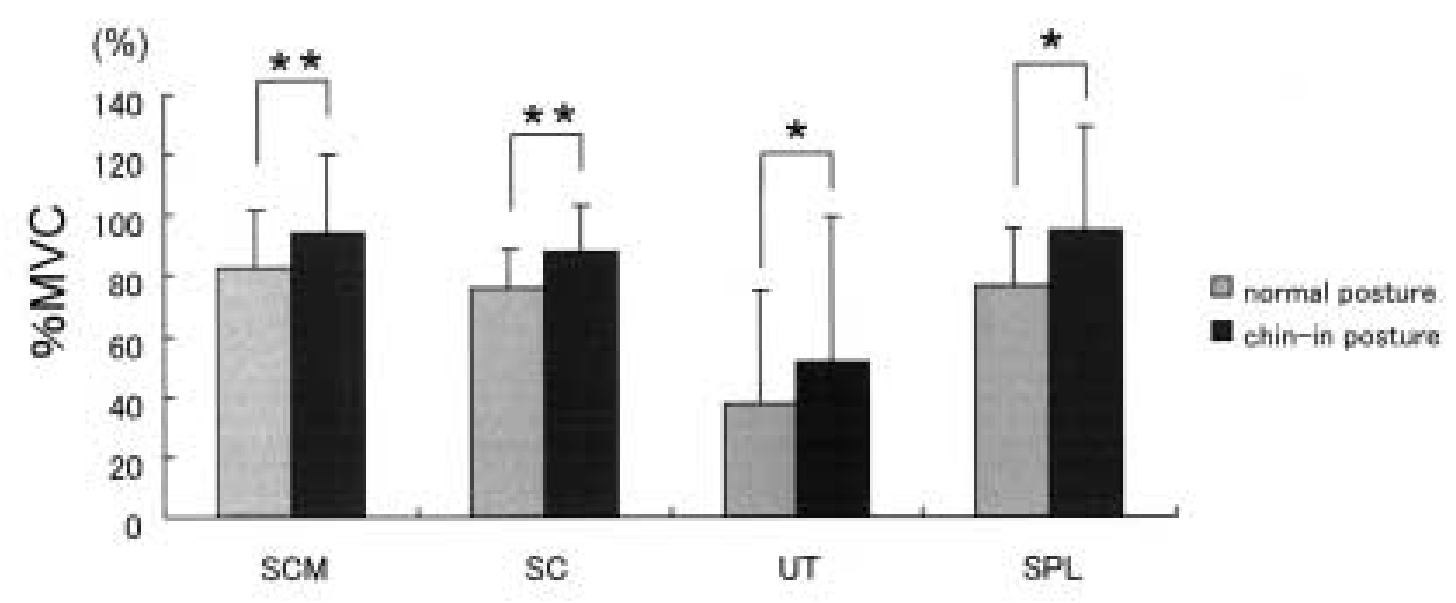

Fig. 5-1. While the MIVC flexion action.

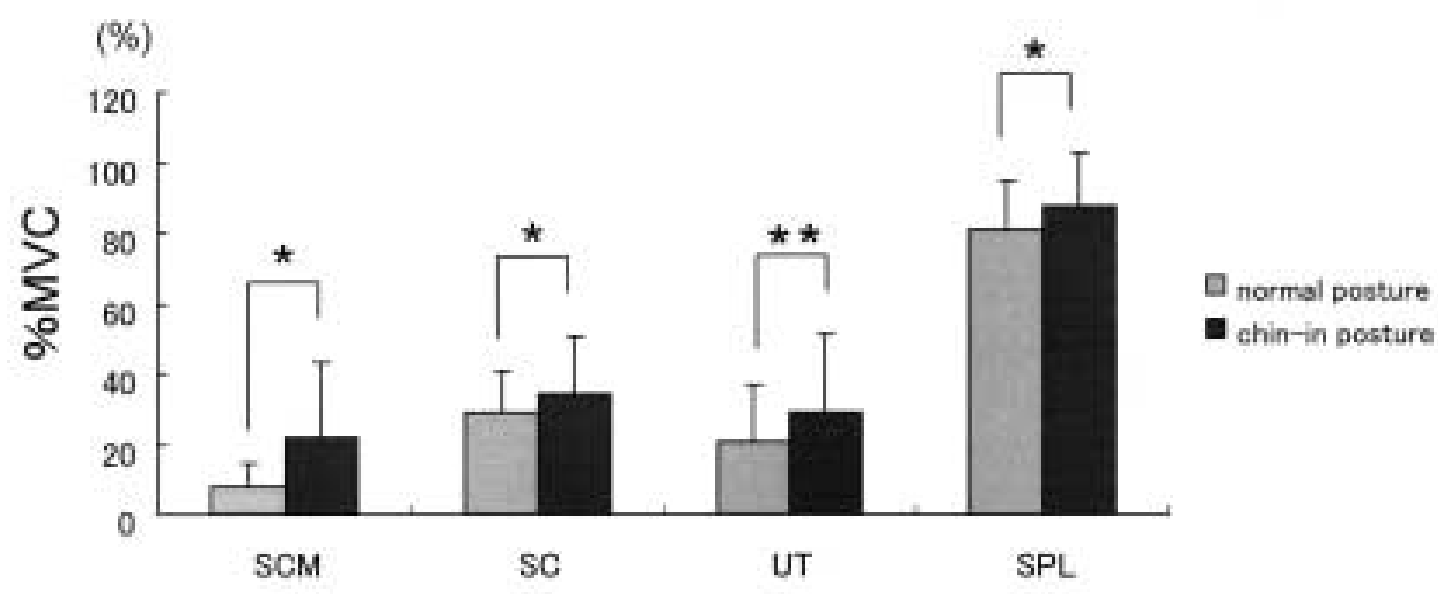

Fig. 5-2. While the MIVC extension action.

Fig. 5. Muscle activities during normal posture and chin-in posture. $* \mathrm{p}<0.05 * * \mathrm{p}<0.01$

SCM : sternocleidomastoid SC: scalenus UT: upper trapezius SPL: splenius. 
Table 1. The rate of increase of EMG during chin-in posture.

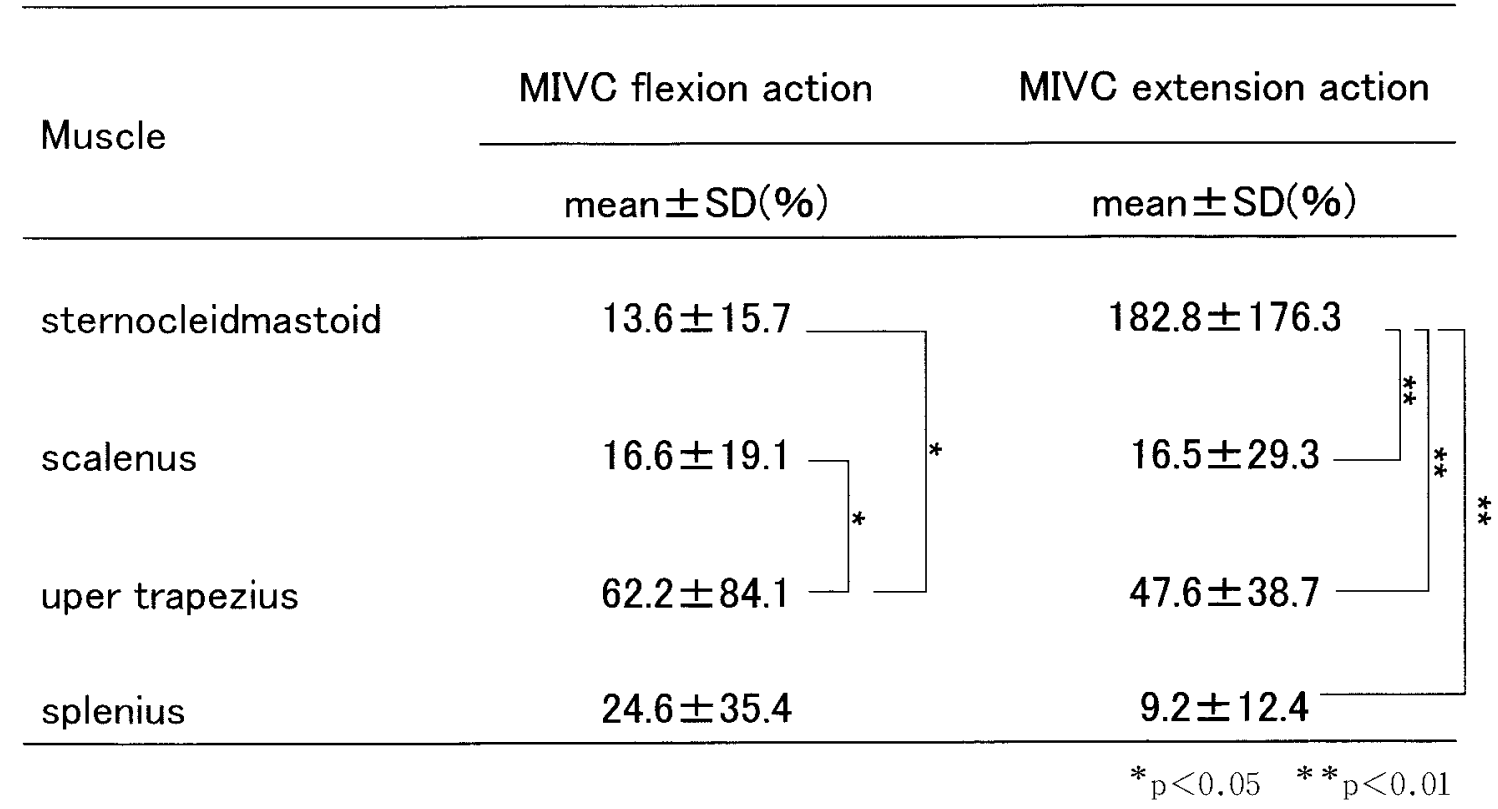

展・側屈させるような, 関節運動を伴った抵抗運動 やブリッジなどは , かえって頚椎に慢性的なストレ スや強い軸圧を与えてしまい, 後弯変形や骨棘形成 などの不可逆な頚椎症性変化をきたす可能性がある とされている3），乥のため，頚部トレーニングは等 尺性収縮で行うことが推奨される．このときに，チ ンイン姿勢をとることで頚部屈曲筋群および伸展筋 群の筋活動を同時に高めることができ, 頚部の安定 性が得られる .このため, チンイン姿勢は安全性の 点からも頚部筋力トレーニングに効果的であると考 えられる .

また，今回の結果からチンイン姿勢は頚部外傷予 防に対しても有効と考えた .チンイン姿勢に比べ， 通常姿勢での頚椎アライメントは前弯しているため 可動性が大きい .このため，㑯部筋を等尺性収縮さ せても屈曲および伸展方向から外力を受けた場合 に, 過伸展, 過屈曲しやすくなる.例えば, 選手が 後方から体当たりされたときに，頭部が後方に残っ た状態で身体が前方へ変位し, 攧部過伸展していわ ゆる鞭打ち樣の損傷を起こすことがある ${ }^{2)}$.さらに， ヘッドアップすなわち顎が前方に突き出されて上が る状態では, 胸鎖乳突筋は頚椎の伸展筋群として作 用し, 前方からの外力に対して弱くなる .この外力 を筋収縮で吸収しきれなくなり，頚部の骨性組織や 椎間板, 鞄帯のような軟部組織に悪影響を及ぼす． さらに, 顎が上がると相手選手とのコンタクトの際
に重要とされる下肢の伸筋群や腹筋の収縮が姿勢反 射のひとつである頚反射のために抑制され，相手選 手からの前方からの衝撃に対して受身が総合的に弱 くなり，障害予防の視点に加えスポーツパフォーマ

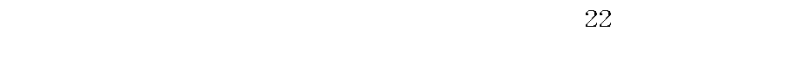
な状況に対して反射的にチンインできるようにする ことが大切と述べられている2).

チンインすることにより頚椎のアライメントが直 線化するため5)，矢状面上での可動性が少なくなる ことが考えられる．乥して，頚部の後部にある頝部 伸展筋群に加え，前側方部にある胸鎖乳突筋，斜角 筋などが同時収縮して頚部全体が胸部にロックされ た状態となる ${ }^{2)}$.これらのことから，チンイン姿勢 は頚部外傷の予防にも有効であると考える.しかし， 実際の競技では相手選手とへッドタックルでコンタ クトした際，最大で頭頚部に約 5,880Nの力が加わ るとされている ${ }^{22)}$.このため, 競技においてチン イン姿勢か頚部外傷予防に本当に効果的であるかに ついては，今後検討が必要である。

$$
\mathrm{V} \text {. 結語 }
$$

1 . 通常姿勢時とチンイン姿勢時の頚部筋力および 筋活動を測定した .

2 . チンイン姿勢時の頚部筋力および筋活動は通常 姿勢時と比べ，有意に高値を示した．

3. チンイン姿勢が頚部トレーニングおよび外傷予 
防に効果的であることが示唆された .

(受理日 平成 20 年 10 月 18 日) 文献

1) 阿部 均.アメリカンフットボールにおける頝部の 外傷・障害 3 . 頚部のメディカルチェックと医学的 な予防対策．臨床スポーツ医学 (1999)，16 (11)， 1251-1258.

2) 高澤祐治, 黑澤 尚, 山本和宏, 永山正隆 . 頚部周 囲の筋力強化方法〜コンタクトスポーツにおける回 復期のリハビリテーション〜 . 整形・災害外科 (2005)，48 (5)，539-546.

3）黑澤 尚, 高澤祐治 .コンタクトスポーツに特有な 外傷 - 頚部の外傷について - .治療 (2006) ,88 (6), 1736-1741.

4) 川野哲英 .ファンクショナルエクササイズ, 第 1 版, 124-127, ブックハウスHD , 東京 , 2004 .

5) Penning, L. The cervical spine, 2nd ed., Function Anatomy of joints and discs., The cervical spine research society editorial committee, (1999), 33-56.

6) 津山 薰, 藤城仁音, 中嶋耕平, 中里浩一, 中嶋寛之 . 大学アメリカンフットボール選手の頚部筋力に関す る研究 競技レベル, 学年, 経験年数を指標として. 体力科学 (1999)，48 (2)，251-263.

7) 野村耕三、頚部疾患における等尺性頚部筋力に関す る臨床的検討 . 山口医学 (1988)，37 (2)，137-152 .

8) Falla, D., Alba, D.P., Rainoldi, A., Merletti, R., Jull, G. Location of innervation zones sternocleidomastoid and scalene muscles - a basis for clinical and research electromyography applications. Clinical Neurophysiology (2002), 113(1), 57-63.

9) Strimpakos, N., Georgios, G., Eleni, K., Vaailios, K., Jacqueline, $O$. Issue in relation to the repeatability of and correlation between EMG and Borg scale assessment of neck muscle fatigue. Journal of Electromyography and Kinesiology. (2005), 15(5), 452-465.

10) Falla, D., Rainoldi, A., Merletti, R., Jull, G. Myoelectric manifestations of strenocleodmastoid and anterior scalene muscle fatigue in chronic neck pain patients. Clinical Neurophysiology (2003), 114(3), 488-495.

11) Helen J. Hislop, Jacqueline Montgomery 著, 津山直一 訳. 新. 徒手筋力検査法, 協同医書出版社, 東京, (2003).

12) 下条仁士 . アメリカンフットボールにおける頚部の 外傷・傷害 1 . 頊部外傷の実態と発生機序. 臨床 スポーツ医学 (1999)，16 (11)，1233-1240.

13) Funk, F. F., Wells, R. E. Injuries of the cervical spine in football. Clin Orthop Relat Res, (1975), (109), 50-58.

14) Albright, J. A. Head and neck injuries in college football : An eight year analysis. American J. Sports Med., (1985), 13(3), 147-152.

15) Torg, J. S., Gulle J. T., Jaffe S. Injuries to the cervical spine in American football players. J Bone Joint Surg Am, (2002), 84-A(1), 112-122.

16) Torg, J. S., Truex, R., Quedenfeld, T. C. The national football head and neck injury registry. JAMA, (1979), 241 (14), 1477-1479.

17) Bauer, J. A., Thomas, T. S., Cauraugh, J. H., Kaminski, T. W., Hass, C. J. Impact forces and neck muscle activity in heading by collegiate female soccer play. ers. J. Sports Sci, (2001),19(3), 171-179.

18）津山薫, 山本洋祐, 中里浩一, 中嶋寛之 . 柔道競 技者における動的な頚部筋カトレーニングが禎部の 筋力と筋断面積に及ぼす効果 . 体力科学 (2005)，54 (3) , 249-258 .

19) 下条仁士 .リハビリテーションプログラム一早期復 帰のためのトレーニング指導一〔13]バーナー症候群 . 臨床スポーツ医学 (1998)，15 (9)，1015-1019.

20) 岡本直輝, 伊坂忠夫, 福川 敦. 頚部の筋カトレー ニングと脱トレーニングが頚部筋力に及ぼす影響 . 体力科学 (1997)，46 (2)，201-210.

21) Conely, M. S., Meyer, R. A., Bloomberg, J. J., Feeback, D. L., Dudley, D. A. Noninvasive analysis of human neck function, Spine, (1995), 20(23), 2505-2512.

22) 下篠仁士 .バイオメカニクスからみたアメリカンフッ トボールに頚椎損傷予防 .臨床スポーツ医学 (2001)， 18 (1) , 59-64. 